УДК 159.9:378-051

doi: $10.15330 / p s .10 .1 .74-80$

Галина Дубиак

Відкритий міжнародний університет розвитку людини «Україна»

galyna.dubchak@gmail.com

\title{
ОСОБЛИВОСТІ ПРОЯВІВ СТРЕСОВИХ СТАНІВ СУЧАСНИХ СТУДЕНТІВ ЗАКЛАДІВ ВИЩОЇ ТА ПРОФЕСІЙНОЇ ОСВІТИ
}

У статті представлені результати емпіричного дослідження особливостей стресових реакиій, які проявляються в навчальній діяльності сучасних студентів, щзо навчаються в закладах вищої та професійної освіти. Обгрунтовано актуальність вивчення проблеми навчального стресу сучасних українських студентів. Описано процедуру дослідження з використанням методики вивчення навчального стресу Ю. В. Щербатих та вибірку, яка нараховувала 600 студентів освітніх закладів міста Чернівиі, серед яких студенти закладів вищої освіти склали 316 осіб, професійних училищ - 284. Серед досліджуваних було 283 чоловіків та 317 жінок. Вік досліджуваних студентів - від 15 до 45 років. На основі аналізу результатів емпіричного дослідження вивчено психологічні особливості проявів стресових станів сучасних українських студентів, щзо навчаються в закладах вищої та професійної освіти, визначено їхні спільні та відмінні особливості. 3 'ясовано, що за останнє десятиліття в загальній картині стресу зросла значущість проблем, пов 'язаних з навчальною діяльністю та повсякденним функціонуванням студентів. Найбільш вираженими проявами навчальних стресів сучасних українських студентів є поведінкові, наймени вираженими - фізіологічні. Рівень екзаменаційного стресу студентів закладів вищої та професійної освіти є істотно вищим, ніж десятиліття тому (дослідження Ю. В. Щербатих, 2006). Рівень стресового навантаження студентів закладів вищої освіти $\epsilon$ значно вищим, ніж в учнів професійних училищ. Дослідження дозволило виявити низку проблем, які потребують иілеспрямованої системної роботи, оскільки в усіх групах досліджуваних виявлено факт вживання частиною студентів алкоголю, наркотиків та паління сигарет. Саме иі особи, передусім, потребують психологічної допомоги фахівиів щуодо ефективних прийомів зняття стресового навантаження.

Ключові слова: студенти, стрес, екзаменачійний стрес, стресові стани студентів.

Постановка проблеми і актуальність дослідження. Навчальна діяльність у вузі $\epsilon$ одним з найбільш напружених видів діяльності. Для молоді, що отримує освіту, період навчання є тривалим і складним процесом, що вимагає великих інтелектуальних і фізичних зусиль, емоційної стійкості, психологічної врівноваженості, досягнення поставлених цілей і подолання стресових ситуацій, особливо в період екзаменаційних сесій.

Стрес є невід'ємною частиною студентського життя. Він викликає емоційні реакції, які, переважно, негативно впливають на організм і заважають ефективній навчальній діяльності. Зокрема Наєнко Н. підкреслює, що в період екзаменаційної сесії у студентів виникає психічне напруження, яке в деяких випадках призводить до появи невротичних розладів. Результати інших досліджень переконливо показують, що навчальний стрес впливає на протікання процесів уваги, мислення, пам'яті та, в цілому, на успішність навчальної діяльності студентів (Гапонова С., 2005). Труднощі з успішністю в свою чергу викликають дискомфорт, що ще більше посилює загальний стрес. Тому вивчення психологічних аспектів навчального стресу студентів $\epsilon$ важливим аспектом сучасних психологічних досліджень не тільки в теоретичному, але і практичному плані, зокрема для вирішення завдань профілактики, ранньої діагностики та психокорекції різних психологічних розладів у студентів, а також для забезпечення їхньої високої працездатності в навчальній та майбутній професійній діяльності.

Аналіз останніх досліджень. У психологічній літературі багато досліджень присвячено психологічним аспектам стресу (Сельє Г., 1960, 1979; Лазарус Р., 1988; Фолкман С., 1988; Китаєв-Смик Л., 1983; Титаренко Т., 1998; Карамушка Л., 2004; Бодров В., 2006; Хуторна М., 2007; Бохан Т., 2008; Крайнюк В., 2007 та ін.). Однак проблемі стресу і стресових ситуацій в навчальній діяльності присвячено не багато праць (Гринберг Дж., 2002; Щербатих Ю. 2000, 2006; Гапонова С., 2005; Меньшикова I., 2008; Аракелов Г., 2008 та ін.).

Зокрема, Гапонова С. (2005) вивчала динаміку та детермінанти функціональних 
психічних станів студентів в освітньому просторі вузу. Структуру особистісного компоненту стресостійкості студентів в ситуації інтелектуальних випробувань і групу психологічних факторів, які гальмують процес розвитку стресостійкості досліджувала Хуторна М. (2007). Схожою проблемою займалася Меньшикова I. (2008), яка вивчала процес адаптації студентів до екзаменаційних сесій та особливості психологічної допомоги студентам. Сергєєва О. (2008) досліджувала вплив екзаменаційного стресу на навчальну мотивацію студентів вузу. Аракелов Г. (2008) займався проблемою стрес-факторів, які впливають на формування психосоціальної стійкості особистості в період студентства.

Однак у вітчизняній психологічній літературі недостатньо вивчено особливості навчального стресу сучасних українських студентів [1].

Метою статті $\epsilon$ емпіричне вивчення психологічних особливостей проявів стресових станів сучасних студентів, що навчаються в закладах вищої та професійної освіти.

Виклад методики і результатів дослідження. 3 метою вивчення психологічних аспектів прояву навчального стресу українських студентів нами було проведено емпіричне дослідження, в якому взяли участь взяло участь 600 студентів закладів вищої та професійної освіти. м. Чернівці, серед яких студенти вузу склали 316 осіб, а професійних училищ - 284. Серед досліджуваних було 283 чоловіків та 317 жінок. Вік досліджуваних студентів - від 15 до 45 років $(\mathrm{M}=18,89 ; \mathrm{SD}=3,15)$. Середній вік студентів закладів вищої освіти $(20,14 \pm 3,69 ;<16 ; 45>)$ є істотно вищим, ніж професійних училищ $(17,36 \pm 1,148$; $<16 ; 21>)$.

Перевірка нормальності розподілу даних здійснювалася на основі тесту Колмогорова-Смирнова. Розподіл за всіма шкалами $\epsilon$ нормальним $(\mathrm{p}>0,05)$. Тест chi $^{2}$ показав гомогенність груп студентів за статтю, курсом та типом навчального закладу (p $\geq 0,05 ;$ ni).

У дослідженні було використано методику вивчення навчального стресу Щербатих Ю., яка дозволяє виявити фактори, які викликають стрес у студентів; рівень цього постійного стресу; симптоми, що супроводжують стресовий стан; прийоми, які використовуються студентами для зняття стресу; вираженість екзаменаційного стресу та стан здоров'я під час екзамену [2].

Математико-статистичні процедури з аналізу результатів дослідження проводилися з використанням комп'ютерної статистичної програми SPSS (chi², критерій t-Student, дисперсійний аналіз).

Першим кроком нашого дослідження став аналіз значущості окремих проблем у загальній картині стресу студентів (див. табл. 1). Отримані дані нами порівнювалися з середніми значеннями дослідження автора методики [1, с. 209].

Таблиия 1

Значущість проблем у загальній картині стресу студентів ( $=600)$

\begin{tabular}{|c|c|c|c|c|c|c|c|c|c|}
\hline \multirow[b]{2}{*}{ Проблема } & \multirow[b]{2}{*}{ Ma } & \multirow[b]{2}{*}{ M } & \multirow[b]{2}{*}{$\sigma$} & \multirow[b]{2}{*}{$\mathrm{p}$} & \multicolumn{2}{|c|}{$3 \mathrm{BO}$} & \multicolumn{2}{|c|}{ ЗПО } & \multirow[b]{2}{*}{$\mathrm{p}$} \\
\hline & & & & & M & $\sigma$ & M & $\sigma$ & \\
\hline Суворі викладачі & 4,8 & 5,37 & 2,38 & 0,001 & 5,56 & 2,26 & 5,16 & 2,49 & 0,040 \\
\hline Велике навчальне навантаження & 3,4 & 6,77 & 2,43 & 0,001 & 6,82 & 2,04 & 6,73 & 2,79 & 0,652 \\
\hline Відсутність підручників & 4,1 & 5,18 & 2,90 & 0,001 & 5,67 & 2,93 & 4,63 & 2,77 & 0,001 \\
\hline Незрозумілі, нудні підручники & 5,0 & 5,04 & 2,78 & 0,747 & 5,29 & 2,77 & 4,75 & 2,78 & 0,018 \\
\hline Життя далеко від батьків & 5,0 & 4,59 & 3,24 & 0,025 & 5,06 & 3,24 & 3,59 & 3,01 & 0,001 \\
\hline $\begin{array}{l}\text { Невміння правильно розпоряд. } \\
\text { обмеж. фінансами }\end{array}$ & 3,4 & 4 & 2,63 & 0,001 & 4,07 & 2,58 & 3,93 & 3,01 & 0,504 \\
\hline $\begin{array}{l}\text { Невміння правильно організувати } \\
\text { свій режим дня }\end{array}$ & 3,6 & 3,97 & 2,56 & 0,001 & 4,49 & 2,52 & 3,39 & 2,49 & 0,001 \\
\hline Нерегулярне харчування & 3,6 & 4,78 & 2,89 & 0,001 & 5,05 & 2,78 & 4,48 & 2,99 & 0,016 \\
\hline
\end{tabular}


Продовження табл. 1

\begin{tabular}{|l|c|c|c|c|c|c|c|c|c|}
\hline $\begin{array}{l}\text { Проблеми спільного проживання } \\
\text { 3 ін. студентами }\end{array}$ & 2,7 & 3,01 & 2,69 & 0,08 & 2,97 & 2,45 & 3,06 & 2,96 & 0,711 \\
\hline Конфлікт у групі & 3,1 & 2,83 & 2,36 & 0,006 & 2,59 & 2,20 & 3,10 & 2,52 & 0,010 \\
\hline $\begin{array}{l}\text { Зайве серйозне ставлення } \\
\text { до навчання }\end{array}$ & 3,8 & 4,00 & 2,65 & 0,069 & 4,34 & 2,70 & 3,62 & 2,54 & 0,001 \\
\hline $\begin{array}{l}\text { Не бажання вчитися або } \\
\text { розчарування в професії }\end{array}$ & 2,5 & 3,78 & 2,73 & 0,001 & 3,90 & 2,80 & 3,65 & 2,64 & 0,255 \\
\hline Незручність, сором'язливість & 3,3 & 4,07 & 2,73 & 0,001 & 4,18 & 2,76 & 3,95 & 2,69 & 0,303 \\
\hline Страх перед майбутнім & 3,6 & 4,84 & 2,96 & 0,001 & 5,00 & 2,78 & 4,67 & 3,15 & 0,175 \\
\hline Проблеми в особистому житті & 5,3 & 3,81 & 3,06 & 0,001 & 4,17 & 2,95 & 3,41 & 3,14 & 0,002 \\
\hline
\end{tabular}

Примітки: Ма - середні значення автора методики; ЗВО - заклад вищої освіти, ЗПО - заклад професійної освіти.

3 наведених у таблиці 1 даних виникає, що значущість окремих проблем у загальній картині стресу сучасних українських студентів $є$ істотно вищою, ніж у проведеному понад десятиліття тому дослідженні Щербатих Ю. (p<0,05). На основі критерію t-Student встановлено, що особливо зросла значущість проблем, пов'язаних з навчальною діяльністю студентів, психологічних та проблем, пов'язаних з повсякденним функціонуванням. Одночасно істотно менш актуальними є проблеми особистого життя, конфлікти у групі та необхідність жити далеко від батьків. Серед виявлених найбільш вираженими виявилися проблеми, пов'язані з навчальною діяльністю, а найменш вираженими - конфлікти у групі, які, можливо, в даний момент відсутні в житті студентів. Не змінилася з часом значущість проблем, пов'язаних з зайвим серйозним ставленням до навчання та незрозумілими, нудними підручниками (p>0,05). Таким чином, виявлені Щербатих Ю. більше десятиліття тому проблеми залишаються джерелом стресу сучасних студентів, а їхня вираженість стала істотно вищою.

Результати дослідження, наведені у таблиці 1 свідчать про те, що для більшості студентів закладів вищої та середньої освіти спільними та найбільш стресогенними є ті самі ситуації, пов'язані з навчальною діяльністю, а саме: велике навчальне навантаження та суворі викладачі. Крім цього, для студентів 3ВО особливо вираженими є ситуації, пов'язані 3 незрозумілими, нудними підручниками та їхньою відсутністю, зате для студентів ЗПО вони $є$ статистично менш істотними, що $є$ зрозумілим, оскільки у вузах більше уваги приділяється вивченню теоретичних, а у ЗПО - практичних аспектів навчальних дисциплін.

3 наведених даних виникає, що до найбільш істотних проблем студентів 3ВО належить також життя далеко від батьків, значущість якої є статистично вищою, ніж для студентів професійних училищ $(\mathrm{p} \leq 0,001)$. На основі аналізу критерію t-Student виявлено істотні відмінності в значущості більшості проблем сучасних студентів, а саме, вони $€$ більш вираженими у студентів 3ВО, ніж професійних училищ $(\mathrm{p} \leq 0,001)$.

Наступним кроком нашого дослідження стало вивчення динаміки стресу сучасних українських студенів. Результати аналізу наведені у табл. 2.

Динаміка стресу за останні три місяці навчання (\%) (N=600)

Таблиия 2

\begin{tabular}{|l|c|c|c|c|c|}
\hline $\begin{array}{c}\text { Рівень } \\
\text { стресу }\end{array}$ & $\begin{array}{c}\text { Значно } \\
\text { зменшився }\end{array}$ & Зменшився & Не змінився & Незначно зріс & Значно збільшився \\
\hline Вибірка & 16,4 & 10,6 & 39 & 26,5 & 7,5 \\
\hline 3ВО & 19 & 8 & 33 & 30 & 10 \\
\hline 3ПО & 13 & 14 & 46,5 & 22 & 4,5 \\
\hline
\end{tabular}

Примітки: ЗВО - заклад вищої освіти, ЗПО - заклад професійної освіти. 
Наведені у таблиці 2 результати дослідження свідчать про змінність показників стресового навантаження студентів протягом навчального року. 3 наведених даних виникає, що для близько 39 \% сучасних студентів рівень стресу за останні три місяці залишився не змінним, 27 \% - зменшився, однак для 34 \% студентів він збільшився, що свідчить про інтенсивну розумову активність студентів. На основі критерію t-Student встановлено, що виявлені зміни є статистично значущими ( $<<0,001)$ (див. табл. 3$)$.

Табличя 3

\section{Показники стресу за останні три місяці навчання ( $\mathrm{N}=600)$}

\begin{tabular}{|c|c|c|c|c|c|c|c|}
\hline \multirow{2}{*}{$\begin{array}{c}\text { Динаміка стресу за } \\
\text { останні три місяці } \\
\text { навчання }\end{array}$} & \multicolumn{2}{|c|}{ Вибірка } & \multicolumn{2}{|c|}{$3 \mathrm{BO}$} & \multicolumn{2}{|c|}{ ЗПО } & \multirow[b]{2}{*}{$\mathrm{p}$} \\
\hline & M & $\sigma$ & $\mathrm{M}$ & $\sigma$ & $\mathrm{M}$ & $\sigma$ & \\
\hline & 2,98 & 1,15 & 3,04 & 1,24 & 2,96 & 0,71 & 0,168 \\
\hline
\end{tabular}

Примітки: ЗВО - заклад вищої освіти, ЗПО - заклад професійної освіти.

Заслуговує на увагу факт, що порівняльний аналіз динаміки стресового навантаження студентів за типом навчального закладу не виявив статистично значущих відмінностей $(\mathrm{p} \geq 0,05)$. Можна припустити, що зазначені зміни значною мірою пов'язані 3 особливостями вікового розвитку і з однаковою частотою проявляються у студентів закладів вищої та професійної освіти.

Окремим аспектом нашого дослідження стала конкретизація основних проявів стресу, пов'язаного 3 навчальною діяльністю студентів. Отримані дані також порівнювалися нами з середніми значеннями дослідження автора методики (див. табл. 4).

Наведені у методиці Щербатих Ю. прояви стресу можна віднести до когнітивних, поведінкових, емоційних та фізіологічних проявів. Наведені вище дані свідчать, що спільними для сучасних студентів ЗВО і СПО найбільш вираженими проявами навчальних стресів є поведінкові, найменш вираженими - фізіологічні. Це може свідчити про хороший стан здоров'я досліджуваної групи, а стрес у студентів проявляється, в основному, на психологічному рівні.

Таблиция 4

Прояви стресу, пов'язані 3 навчальною діяльністю студентів (N=600)

\begin{tabular}{|l|c|c|c|c|}
\hline \multicolumn{1}{|c|}{ Прояви стресу } & Мa & M & $\sigma$ & $\mathrm{p}$ \\
\hline Відчуття безпорадності & 4,0 & 4,31 & 2,67 & 0,004 \\
\hline Неможливість позбавлення від сторонніх думок & 4,7 & 4,21 & 2,62 & 0,001 \\
\hline Погана концентрація уваги & 3,8 & 4,28 & 2,49 & 0,001 \\
\hline Дратівливість, образливість & 3,5 & 3,99 & 2,64 & 0,001 \\
\hline Поганий настрій, депресія & 4,4 & 4,28 & 2,82 & 0,306 \\
\hline Страх, тривога & 3,8 & 3,66 & 2,7 & 0,210 \\
\hline Втрата впевненості, зниження самооцінки & 2,9 & 3,37 & 2,56 & 0,001 \\
\hline Поспіх, відчуття постійної нестачі часу & 4,5 & 5,13 & 3,01 & 0,001 \\
\hline Поганий сон & 3,9 & 5,38 & 3,31 & 0,001 \\
\hline Порушення соціальних контактів & 2,6 & 3,37 & 2,34 & 0,001 \\
\hline Прискорене серцебиття, болі в серці & 2,6 & 3,00 & 2,74 & 0,001 \\
\hline Утруднене дихання & 2,1 & 2,38 & 2,38 & 0,004 \\
\hline Проблеми з шлунково-кишковим трактом & 3,2 & 2,52 & 2,46 & 0,001 \\
\hline Напруга чи тремтіння м’язів & 2,8 & 2,26 & 1,95 & 0,001 \\
\hline Головні болі & 4,9 & 3,71 & 2,73 & 0,001 \\
\hline Низька працездатність, підвищ. стомлюваність & 5,0 & 3,93 & 2,85 & 0,001 \\
\hline
\end{tabular}

Примітки: Ма - середні значення автора методики. 
Наступним кроком нашого дослідження стало вивчення прийомів, які використовують студенти для зняття стресу (див. табл. 5).

Наведені у таблиці 5 дані частотного аналізу показали, що спілкування 3 друзями або коханою людиною та сон для зняття стресу найчастіше використовує близько 80\% студентів. Також достатньо часто (для близько 50\% студентів) такими прийомами виступають прогулянки на свіжому повітрі, смачна їжа, підтримка або порада батьків та фізична активність студентів. Деяка частина студентів (близько 1,8-16,2\% студентів) для зняття стресу використовує такі прийоми, як паління сигарет, вживання алкоголю та наркотиків. Саме ці особи потребують психологічної допомоги фахівців щодо ефективних прийомів зняття стресового навантаження.

Табличя 5

Основні прийоми зняття стресу студентами (\%) (N=600)

\begin{tabular}{|c|c|c|c|c|c|c|c|}
\hline \multirow[b]{2}{*}{ Прийоми зняття стресу } & \multicolumn{2}{|c|}{ Вибірка } & \multicolumn{2}{|c|}{$3 \mathrm{BO}$} & \multicolumn{2}{|c|}{ ЗПО } & \multirow[b]{2}{*}{$\mathrm{p}$} \\
\hline & $\begin{array}{c}\mathrm{He} \\
\text { викор. }\end{array}$ & Викор. & $\begin{array}{c}\text { Не } \\
\text { викор. }\end{array}$ & Викор. & $\begin{array}{c}\text { Не } \\
\text { викор. }\end{array}$ & Викор. & \\
\hline Алкоголь & 85 & 15 & 83,5 & 16,5 & 86,6 & 83,5 & 0,292 \\
\hline Сигарети & 83,8 & 16,2 & 88,8 & 11,7 & 78,9 & 88,8 & 0,002 \\
\hline Наркотики & 98,2 & 1,8 & 100 & 0 & 96,1 & 100 & 0,001 \\
\hline Телевізор & 63,5 & 36,5 & 71,5 & 28,5 & 54,6 & 71,5 & 0,001 \\
\hline Смачна їжа & 51,3 & 48,7 & 53,2 & 46,8 & 49,3 & 53,2 & 0,344 \\
\hline Перерва в роботі чи навчанні & 62,3 & 37,7 & 58,9 & 41,1 & 66,2 & 58,9 & 0,064 \\
\hline $\mathrm{CoH}$ & 26,8 & 73,2 & 25,6 & 74,4 & 28,2 & 25,6 & 0,484 \\
\hline Спілкув. з друзями або кохан. людиною & 19,8 & 80,2 & 21,5 & 78,5 & 18 & 21,5 & 0,275 \\
\hline Підтримка або порада батьків & 52,3 & 47,7 & 48,4 & 51,6 & 56,7 & 48,4 & 0,043 \\
\hline Секс & 66,8 & 33,2 & 70,3 & 29,7 & 63,0 & 70,3 & 0,061 \\
\hline Прогулянки на свіжому повітрі & 44,2 & 55,8 & 48,1 & 51,9 & 39,8 & 48,1 & 0,041 \\
\hline Хобі & 64,5 & 35,5 & 71,8 & 28,2 & 56,3 & 71,8 & 0,001 \\
\hline Фізична активність & 55,5 & 44,5 & 52,2 & 47,8 & 59,2 & 52,2 & 0,088 \\
\hline
\end{tabular}

Примітки: ЗВО - заклад вищої освіти, ЗПО - заклад професійної освіти.

Порівняльний аналіз результатів дослідження за типом навчального закладу показав, що існують статистично значущі відмінності у використанні сучасними студентами різних прийомів зняття стресу, а саме, студенти ЗПО частіше використовують прогулянки, хобі, перегляд телепередач, паління сигарет та наркотики, натомість студенти ЗВО частіше звертаються за порадою до батьків. Алкоголь, наркотики та сигарети студенти професійних училищ використовують більш як в два рази частіше, ніж студенти ЗВО, що $є$ тривожним фактом і вказує на необхідність цілеспрямованої психологічної роботи зі студентами з високим рівнем прояву навчального та екзаменаційного стресів.

Важливою частиною життя студентів є екзаменаційна сесія, що стало ще одним аспектом нашого дослідження. Ми постаралися з'ясувати, яким є рівень екзаменаційного стресу студентів та його основні ознаки. Результати проведеного аналізу наведені у таблицях 6-7.

Таблиия 6

Аналіз рівня екзаменаційного стресу студентів ( $\mathrm{N}=600)$

\begin{tabular}{|c|c|c|c|c|c|c|c|c|c|c|}
\hline \multicolumn{4}{|c|}{ Вибірка } & \multicolumn{3}{|c|}{ 3ВО } & \multicolumn{3}{|c|}{ 3ПО } & $\mathrm{p}$ \\
\hline Ма & $\sigma$ & $\mathrm{M}$ & $\sigma$ & $\mathrm{t}$ & $\mathrm{p}$ & $\mathrm{M}$ & $\sigma$ & $\mathrm{M}$ & $\mathrm{M}$ & $\sigma$ \\
\hline 6,0 & 0,35 & 7,27 & 2,75 & 62,296 & 0,001 & 7,63 & 2,17 & 6,89 & 3,21 & 0,002 \\
\hline
\end{tabular}

Примітки: Ма - середні значення автора методики; 3ВО - заклад вищої освіти, ЗПО - заклад професійної освіти.

Наведені вище дані свідчать про те, що рівень екзаменаційного стресу студентів виносить 7,25 балів за 10-бальною шкалою, що є тривожним фактом, оскільки саме 
екзамен виступає найсильнішим фактором, що провокує появу стресів в період навчання. Цей показник $\epsilon$ істотно вищим, ніж у дослідженні Щербатих Ю. $(p<0,05)$. Таким чином, можемо констатувати зростання рівня екзаменаційного стресу сучасних студентів за останне десятиліття.

Під час сесії студенти практично без перерв опрацьовують і засвоюють якісно різні навчальні предмети, що вимагають інших прийомів мислення, запам'ятовування, кожного разу особливої логіки підготовки. Це супроводжується постійними переживаннями через невизначеність результатів праці (екзаменаційної оцінки), відповідальності перед батьками, небажання втратити престиж в групі. Тому стреси, що виникають в період сесії, часто приймають хронічний і до того ж комбінований характер, оскільки викликаються одночасною дією декількох чинників. Неодноразова або тривала дія комплексу стресових впливів з недостатньою стійкістю нервової системи і організму в цілому утруднює цілеспрямовану розумову роботу, знижує ефективність праці студентів, погіршує результативність їх діяльності. Відтак деякі студенти здають іспити гірше, ніж навчаються під час семестру. Заслуговує на увагу той факт, що рівень екзаменаційного стресу студентів 3ВО є істотно вищим $(\mathrm{M}=7,63, \sigma=2,17)$, ніж у студентів професійних училищ $(\mathrm{M}=6,89, \sigma=3,21)$.

Цікавим виявився аналіз ознак екзаменаційного стресу студентів. Наведені у таблиці 7 дані частотного аналізу показують, що найчастіше основною ознакою екзаменаційного стресу студентів закладів вищої та середньої освіти $є$ прискорене серцебиття (73\%); достатньо вираженими є також головні чи інші болі $(42,2 \%)$. Майже третина студентів скаржиться на скутість, тремтіння м'язів та сухість у роті; інші ознаки екзаменаційного стресу виявляються у незначної частини студентів. Однак виявлені відмінності не $\epsilon$ істотними статистично ( $\mathrm{p} \geq 0,05)$.

Таблиия 7

Ознаки екзаменаційного стресу студентів (\%) (N=600)

\begin{tabular}{|c|c|c|c|c|c|c|c|}
\hline \multirow{2}{*}{$\begin{array}{c}\text { Ознаки екзаменаційного } \\
\text { стресу }\end{array}$} & \multicolumn{2}{|c|}{ Вибірка } & \multicolumn{2}{|c|}{$3 \mathrm{BO}$} & \multicolumn{2}{|c|}{ ЗПО } & \multirow[b]{2}{*}{$\mathrm{p}$} \\
\hline & Відсутні & Наявні & Відсутні & Наявні & Відсутні & Наявні & \\
\hline Прискор. серцебиття & 27 & 73 & 27 & 73 & 27 & 73 & 0,900 \\
\hline Сухість у роті & 70,3 & 29,7 & 70 & 30 & 70 & 30 & 0,964 \\
\hline Утруднене дихання & 75,8 & 24,2 & 78 & 22 & 78 & 22 & 0,159 \\
\hline Скутість, тремтіння м’язів & 68 & 32 & 71 & 29 & 71 & 29 & 0,155 \\
\hline Головні чи інші болі & 57,8 & 42,2 & 58 & 42 & 58 & 42 & 0,991 \\
\hline
\end{tabular}

Отже, результати проведеного аналізу свідчить про неоднорідність студентського середовища: поруч зі студентами, які, стикаючись із навчальними труднощами і проблемами, вирішують їх конструктивно або відносно конструктивно, $\epsilon$ студенти 3 недостатньо високими адаптаційними здібностями.

Висновки. На основі викладених вище результатів емпіричного дослідження можна зробити наступні висновки:

За останнє десятиліття в загальній картині стресу зросла значущість проблем, пов'язаних з навчальною діяльністю та повсякденним функціонуванням студентів. Водночас, істотно менш актуальними стали особисті проблеми, пов'язані $з$ проживанням далеко від батьків та конфлікти у групі.

Найбільш вираженими проявами навчальних стресів сучасних українських студентів є поведінкові, найменш вираженими - фізіологічні;

Рівень екзаменаційного стресу студентів закладів вищої та середньої освіти є істотно вищим, ніж десятиліття тому. Рівень стресового навантаження студентів ЗВО є значно вищим, ніж в учнів професійних училищ. 
Для зняття стресу більшість сучасних українських студентів найчастіше використовує спілкування з друзями або коханою людиною та сон, а також прогулянки на свіжому повітрі, смачну їжу, підтримку або поради батьків та фізичну активність.

Таким чином, результати проведеного аналізу вказують про необхідність цілеспрямованої психологічної роботи зі студентами з високим рівнем прояву навчального стресу, що буде перспективою наших подальших розвідок у даному напрямі.

1. Дубчак, Г. М. (2017). Психологічні основи професійної стресостійкості майбутніх фахівиів. К.: Талком.

2. Щербатых, Ю. В. (2006). Психология стресса и методы коррекиии. СПб.: Питер.

\section{REFERENCES}

1. Dubchak, H. M. (2017). Psyholohichni osnovy profesijnoyi stresostijkosti majbutnix fahivciv [Psychological bases of professional stress resistance of future specialists]. K.: Talkom. (ukr).

2. Shherbatyh, Ju.V. (2006). Psihologija stressa i metody korrekcii [Psychology of stress and methods of correction]. SPb.: Piter. (rus).

\section{Halyna Dubchak \\ FEATURES OF EXPRESSIONS OF STRESS AMONG MODERN STUDENTS OF HIGHER AND PROFESSIONAL EDUCATION}

The article presents the results of empirical research of features of stress reactions that occur in learning activities of modern students of universities and vocational schools. The importance of studying the problem of educational stress of modern Ukrainian students is substantiated. There is described the procedure of research with the use of methods of study of the educational stress Shcherbatykh Y. Research sample amounted to 600 students from Chernivtsi, including 316 students of institutions of higher education and 284 vocational schools students. Among surveyed were 283 men and 317 women. The age of the surveyed students was from 15 to 45 years. On the basis of the analysis of the results of the empirical research author determined psychological features of the manifestations of stress among modern Ukrainian students of institutions of higher and secondary education. Their common and distinctive features were identified. It was revealed that during the last decade the importance of problems related to the educational activities and the daily functioning of students has increased. The most severe manifestations of academic stress of modern Ukrainian students are behavioural, the least severe - physiological. The level of examination stress among students of Universities and vocational schools is considerably higher than a decade ago (Shcherbatykh Y. research, 2006). The level of stress load of students of institutions of higher education is much bigger than the level of stress load of students of vocational schools. The study revealed a number of problems that require focused systematic work, because in all groups of surveyed students was found out that some of them use alcohol, drugs and cigarettes. These persons, in particular, are in need of specialist psychological care on effective methods of reducing the stress load.

Keywords: students, stress, examination stress, stress condition of students. 